\title{
Lived religion and mystical experiences
}

\section{Finding an inclusive umbrella concept for varieties of experiences deemed religious}

DOI: https://doi.org/10.30664/ar.111061

(c) Attribution 4.0 International (CC BY 4.0)

$\mathrm{T}$ his article discusses and argues for a 'new' and inclusive umbrella concept for varieties of experiences that have been called, inter alia, religious, spiritual, existential, paranormal, extraordinary or inexplicable. The umbrella concept to be explored is seen as a means of capturing one kind of 'lived religion' in contemporary society and simultaneously expanding the field of the sociology of religion. The discussion is theoretical and anchored in contemporary theories and traditions in sociology of religion, but it is also of pragmatical, methodological, empirical, and ethical concern. The main concepts that are currently in use and considered as offering a possible umbrella term for this cluster of often overlapping experiences, which are difficult to clearly define and distinguish, are summarized, and the main concepts, such as religious, spiritual and paranormal experiences, are elaborated in more detail. Thereafter follows a definition and in-depth discussion of the suggested concept of mystical experiences. In conclusion, I argue that William James's concept of mystical experiences, with an upgraded and inclusive understanding considering religious, cultural and societal change, has the potential to work on etic, interdisciplinary and emic levels, without offending the experiencers or violating their interpretations and the meaning-making of their experiences.

\section{Introduction}

Empirically, when researchers have tried to capture experiences that have been called, inter alia, religious, spiritual, existential, paranormal, extraordinary or inexplicable, traditional terms such as religious or spiritual have not always been the most fruitful, given religious, cultural and societal change. After dealing with this problem of finding an inclusive umbrella concept for these kinds of experiences in different projects, through analyses and deliberation, I have returned to the philosopher and psychologist William James's (1902) concept of mystical experiences, ${ }^{1}$ albeit with an updated understanding and usage. Nordic scholars of religion have usually preserved and viewed mystical experiences as an orientation within institutional religions or mysticism (see e.g. Sorgenfrei 2013).

1 In Swedish I have translated mystical experiences as mystiska erfarenheter and not mystikupplevelser as is usually done in the psychology of religion. In English I am not calling it 'mysterious experiences', in order to lean towards a tradition and James's definition, avoiding adding another term among the hundreds already existing. Furthermore, the abbreviation ' $\mathrm{ME}$ ' for mystical experiences works well both in English, i.e. internationally, and in a Swedish translation, though translating experiences as upplevelser in Swedish would be abbreviated 'MU'. 'ME' also highlights and indicates that it concerns subjective experiences. 
However, James's definition and concept of mystical experiences can be understood to include different experiences of these kinds, interpreted both within and outside institutional religions. This is crucial when considering religious, cultural and societal change, as these experiences are not restricted to religious institutions; rather, they are relatively common human experiences both within and outside institutional religions. According to recent research, as many as up to every other person in socalled secularized societies has had some kind of mystical experience (see below).

It is always relevant to evaluate and discuss the established concepts used in academia and their usefulness, since they are contextual constructions, time-bound and time-limited, and may change or lose meaning over time. The consequences might therefore be negligence or omission of a kind of 'lived religion' and religiosity in contemporary so-called secularized society. Hence, concepts are not only theoretical but of pragmatical and empirical methodological concern. For instance, do people understand what we as researchers are asking for and trying to capture? How do the researcher's terms affect the informants and the answers received, or not received? In other words, what do terms 'do' to the informants? Especially when turning to the public it can be crucial to select an everyday term that people can easily understand and relate to. There are also ethical aspects regarding the informants to consider, such as trying to avoid terms and formulations that could be perceived as threatening, questioning or judgemental (see Castro 2009: 32-4). This is also a matter of creating trust and conditions in which people are willing to share their stories and experiences. In addition, the use of concepts by researchers also raises questions of how science can be made more open and comprehensible outside specific disciplines and fields of expertise.

Important too is the fact that the use of concepts is related to the construction of knowledge and power. Relevant here are the concepts of construction of the first and second orders by sociologists Patrik Aspers (2011) and Anthony Giddens (1984). The first-order construction, and first-order terms, refer to the interpretations of the informants and what ordinary people might call their experiences (emic), in contrast to the second-order construction, and second-order terms, that researchers use (etic), based on their interpretations, categorizations, use of theories and purpose of the research (Aspers 2011: 46-9). Giddens also uses the concept of 'double hermeneutics', that is a 'double' process of interpretation that involves two meaningmaking processes, partly the meaning that people construct in their everyday life, partly the meaning and the meta-language that researchers construct. There is, according to Giddens, also a constant 'slippage' between these two constructions in the practice of research (Giddens 1984: 284, 374). The scholar of religion Ann Taves also discusses this 'bottom-up' and 'top-down' issue, and refers, among other things, to the philosopher of religion Wayne Proudfoot, who claims that the subject's experiences should be described by the researcher in such a way that the subject recognizes herself or himself (Taves 2009: 10, 89-90, 93, 126, 131).

Taves, among others, also argues against the notion that religious experiences (with emphasis on the plural) should be regarded as something sui generis, that is something that is unique in its nature and of its own kind. Instead, Taves alleges that it is human experiences that have been given religious attributes; hence the issue is one of how certain experiences become religious. 
Taves emphasizes above all that the main problem with the sui generis model is that it prevents research on processes concerning how people deem something religious or special, because the approach is limited to what researchers consider to be religious (Taves 2009: 17-22). Furthermore, there is the historical classical struggle and division in psychology of religion between perennialism, that is a notion that religious experiences share an underlying common denominator or a consciousness through time and traditions, and constructivism, that they are merely social and cultural constructions in time and space (see e.g. pp. 20-1, 56-8, 64, 109). However, there does not need to be a contradiction between a perennialist and a constructivist view. It can be argued that human experiences are given meaning across time and space, and are interpreted depending on historical and socio-cultural contexts and the individual's life narrative and conceptualization. In other words, similar experiences in different times and spaces can be interpreted in different ways. For instance, Ezekiel's vision and revelation in the Bible (Ezekiel 1) may today be interpreted as a UFO (Kripal 2011: 144-5). Nonetheless, an appropriate term in the time and place at which the research is conducted is unavoidable in order to convey what one is looking for and intends to investigate.

To sum up the background of this article, I have been looking for an inclusive umbrella term for a cluster of often overlapping experiences and events that can be difficult to define for both researchers and research subjects, as they do not fit in any clearly demarcated category or handy little box. This concept could be likened to the philosopher Ludwig Wittgenstein's (2021/1953) idea of family resemblance. Wittgenstein's parable is that all games (in this case a certain kind of experiences) belong to $a$ family with different members and that some members may have some similarities with some members but fewer with others. My exploration has resulted in an updated, and more inclusive, understanding of James's concept of mystical experiences, which I argue has potential to work as an umbrella term for these kinds of experiences, both at an etic, interdisciplinary, and emic level, and be understood empirically by the public and the informants without offending the experiencers or violating their interpretations and meaning-making processes. ${ }^{2}$ Reference to James is a common denominator within the different disciplines that investigate these kinds of experiences. Hence, with an interdisciplinary objective and the prospect of adding a sociological perspective to this field of research, an accepted and recognized concept such as James's could at least hypothetically work across disciplinary boundaries and build bridges between them.

In the rest of this article, I first anchor my discussions in contemporary theories and traditions in the sociology of religion, with which the concept of 'mystical experiences' can be aligned. This is followed by a summary of the main concepts that are in use in previous research and have been considered as possible umbrella terms for these kinds of experiences. This also illustrates the complexity of this field of research. Finally, the most promising concept I have found, 'mystical experiences', is defined and discussed, describing how an updated understanding of this concept has potential to work in contemporary society.

2 In my ongoing research project, which involves the collection of material in Finland and Sweden in cooperation with the Cultural Sciences Archive Cultura at Åbo Akademi University and Folklife Archives at Lund University using an open web-questionnaire, I am exploring the use of the concept 'mystical experiences' empirically. 


\section{Anchoring the concept 'mystical experiences' in contemporary theories and traditions}

Few studies have been conducted on the subject of individual experiences in the discipline of the sociology of religion, which is my main theoretical perspective. Still, the umbrella term I am searching for can be anchored in theories and traditions of sociology of religion.

Concepts such as 'religion' and 'religiosity' are elusive and versatile, and a recurring problem to define (see e.g. Woodhead 2011; Willander 2014; Thurfjell 2016; Johansson 2018). There is no generally recognized theoretical definition, but religion and religiosity are defined in each study in accordance, for instance, with the research tradition in which the study is located, and the researcher's viewpoint. Among others, the sociologist of religion Erika Willander (2014, 2015; also see Ammerman 2016: 87 ) problematizes what counts as religion in sociology, criticizing the established way of operationalizing, measuring and analysing religion in sociological studies, particularly the frequently Christian understanding of religion. Hence, instead of trying to approach religion as a universal category almost impossible to define, the focus is on certain aspects of a cluster of cultural phenomena and human experiences interpreted both within and outside what is usually recognized as religion (see Thurfjell 2016: 265). This implies that there is no clear demarcation between the notion of 'religious' and 'secular', or religion and culture; religiosity is in many ways a 'floating phenomenon' embedded in the culture (see e.g. Hammer 2004; Partridge 2004; Rosén 2009; Selberg 2011; Holm 2011; Frisk 2014; Heelas 2014; Moberg and Ståhle 2014; Burén 2015).

\section{'Lived religion' and meaning-making}

Several contemporary sociologists of religion, for instance Meredith McGuire (2008b) and Nancy Ammerman (2014, 2016), advocate the study of so-called 'lived religion', that is how people 'do', live and express religiosity in their lives. ${ }^{3}$ Mystical experiences could be considered as a kind of 'lived religion', since they include religiosity in a broad pragmatic sense, both within and outside religious institutions and traditions, involving agency, embodiment and emotions, but not necessarily beliefs. ${ }^{4}$ McGuire (2008a) is also known for a theory of meaning systems, following in the footsteps of the sociologist of religion Thomas Luckmann (1967) and his functional view of religion and religiosity as meaning-making of 'ultimate significance, which could also be understood as a kind of 'doing' and agency. According to Luckmann and McGuire, people's systems of meaning, which can include both socalled religious and secular elements, for example of popular psychology and popular culture, form the basis of how people interpret their experiences, but the interpretations are not necessarily logical or consistent with each other.

The meaning-making and interpretation of these kinds of experiences are also in alignment with Luckmann's and the philosopher and social phenomenologist

3 For an overview of this shift and turn to 'lived religion' in the sociology of religion from the 1990s, see Ammerman 2016.

4 In contrast to research on 'lived religion' in a Nordic context the major trend in America has been to associate 'lived religion' with non-institutional religion (Ammerman 2016). Furthermore, emotions are also a relatively new research subject within the sociology of religion (see Riis and Woodhead 2010; Luhrmann 2012; Ammerman 2016). 
Alfred Schütz's theories of multiple realities, provinces of meaning and transcendence (Schütz 1982/1962; Schütz and Luckmann 1973, 1990). Schütz asserts that different provinces or 'main departments', such as dream, fantasy, art or religious experiences, are used in parallel in people's construction of meaning. The province that the individual uses in the meaning-making construction of different experiences is determined by several different factors, but the reality of everyday life that people share with others, and which is 'taken for granted', is paramount. According to Schütz people do not usually abandon the dominant understanding of reality without having experienced a shock that forces a shift from the self-evident understanding of reality to another province (Schütz 1982/1962: 207-9, 231-2). The kind of experiences or events that I am interested in could be considered as a minor or significant 'shock' relative to the 'taken-forgranted reality', or the paramount 'social construction of reality' (Berger and Luckmann 1966).

By 'reduced transcendence and increased religiosity', Luckmann (1990) concludes that the human subjective experience of transcendence is universal but its scope has decreased from being primarily about a 'great' transcendence of God according to the church's understanding, to 'minimal' but increased temporal and spatial, privatized and individualized transcendence, related to pivotal contemporary values in society, such as self-realization, autonomy and subjective self-expression (also see Inglehart 2006 and below). Later Luckmann also asserts that individualoriented religion probably draws inspiration from currents of thought in magic and so-called 'new spirituality' (Luckmann 1990: 138). Luckmann's theories of 'invisible religion' and 'privatized syncretism' can be encapsulated as a religious reorganization and a fundamental change of the place of religion from institution to individual, and individual constructed systems of meaning. However, individuals' meaning-making processes and interpretations of these experiences are not, from a sociological perspective, isolated or detached phenomena, but take place in a specific context, time and space, together with or in relation to other people at both a meso and macro level.

To summarize, there is a genealogy and linkage between James, Schütz, Luckmann (and Berger), McGuire and later 'lived religion'; and a discussion to continue and contribute to with this understanding of the concept of mystical experiences.

\section{Contemporary society and the taken-for- granted reality}

At a macro level the concept of mystical experiences can be theoretically consistent with theories of contemporary society such as Giddens's (1999) theory of a latemodern society, that is a post-traditional reflexive society strongly influenced by modernity, capitalism and consumption, in which people are questioning, constructing, and constantly revising their life stories to be 'true to oneself'. Giddens believes this will also give rise to new religious and spiritual currents and human existential questions concerning self-realization. In line with this are the philosopher Charles Taylor's (1989) and the sociologists of religion Paul Heelas and Linda Woodhead's (2004) theories of a cultural shift from an authoritarian to a more subjective valuebased approach. In other words, existential issues, and religiosity in all its different forms, seem to be an important part of late-modern self-expression, reflexivity and meaning-making, including appraising subjective experiences. However, it is 
not a matter of 're-enchantment' in contemporary society, as Taylor (2011) asserts, referring to the classic sociologist Max Weber's (1964/1922) term 'disenchantment', since the 'enchanted' in pre-modern times seemed to be as real as the physical world. Hence, questions such as 'Have you experienced a ghost or a spirit?' would be equivalent to 'Have you experienced the ocean?', which is not usually the case in contemporary society. Rather the shared 'taken-for-granted reality' could be called a 'natural scientific consensus view of reality' (Tegmark 2014).

However, this does not mean precluded materialism, nor does it mean that other worldviews, dimensions or provinces (see above) are not also possible or that people do not make meaning of their mystical experiences. In fact, experiences of these kinds seem to be relatively common in socalled secularized countries, ranging from about ten to fifty per cent of the population, depending on studies and the operationalization and formulation of the questions in the surveys (see e.g. Ahlstrand and Gunner 2008; Laghé 2008: 152; Castro 2009: 18-22; Castro et al. 2013; French and Stone 2014: 6). As the historian of religion Mikael Rothstein puts it, 'religious imagination never left' (Rothstein 2014: 129; also see Hammer 2004), though some thought it did. Furthermore, the historian and philosopher Jason Ananda Josephson-Storm (2017) proclaims that 'disenchantment' of the Western world is a myth. It is a metastory constructed by the academic elite, not least sociologists, but owing to their position of power in society and legitimization, this narrative has been internalized and led to secular norms preventing people from expressing it. According to Josephson-Storm's interpretation, Weber regarded mysticism as the only possibility left for religion in 'disenchanted' modernity and the resolution out of the 'iron cage'. The main problem, Josephson-Storm alleges, is that 'disenchantment' is often regarded as a synonym of secularization and modern rationalization; though the concepts are related, 'disenchantment' is rather a concern within Protestantism (JosephsonStorm 2017: 284-5, 293).

Nonetheless, the prevailing secularization narrative, not least among the public, needs to be considered when selecting an appropriate umbrella term for these kinds of experiences. The secularization narrative calls for a long discussion, but it will not be elaborated on in this article (see e.g. Casanova 2011, 2019; Lövheim and Nordin 2015: 25-7; Willander 2015: 54-5, 65-7; Willander 2019). In short, according to my approach, secularization in a Nordic context could be understood as a process in the general population of the decreasing importance of and association with institutional religion and decreasing numbers of members in the church, but also of religious diversity and pluralism with respect to both institutional religions, taking into consideration immigration and globalization, and individual forms of religiosity and meaning-making. Hence, there does not need to be a contradiction between calling oneself secular or non-religious and considering one's experiences of these kinds meaningful or having an individual 'belief in something?

Furthermore, regarding socialization, media and popular culture permeate today's society and are also 'taken for granted' (see e.g. Partridge 2004; Hjarvard 2012), influencing people's interest in and meaningmaking of these kinds of experiences, such as interpretations of mystical experiences as ghosts (see e.g. Baker and Bader 2014), or making meaning of 'ultimate significance' when interpreting popular fiction films (Axelson 2014). On the other hand, 
the concept of 'mystical experiences' may not be approbated by certain individuals at a micro level, or subcultures or groups at a meso level, that may have their own systems of meaning, either a subjective personal internal or an inter/intra system of meaning according to the group's construction of meaning and interpretation, but this is unavoidable and applies to any term. Also, in other societies an appropriate umbrella term for these kinds of experiences may be different, but in this case it concerns so-called secular and secularized societies, such as the Nordic countries, in which people in general take a natural scientific understanding of reality for granted (see e.g. Morhed 2000; Taylor 2011; Haimila 2020).

\section{The main etic terms used in previous research}

Though explored infrequently in the discipline of the sociology of religion, many scholars within disciplines such as religion, psychology, anthropology, ethnography, science of culture and art have explored the kinds of experiences I am interested in. To date, there is no uniform terminology; rather there is a variety of terms used both within and between different disciplines (see Figure 1 ). ${ }^{5}$ As a reminder, at the time

5 The concept analysis has been conducted in relation to recurring synchronous terms and is to some degree diachronic in the sense of being a comparison between the meanings of a concept in a certain historical time and space (see Kurunmäki and Marjanen 2018: 185). The difficulty with concepts and understandings may become even more problematic in interdisciplinary collaboration, but the aim is not to replace other more specific terms. Other concepts may also work or be more appropriate in some disciplines and research projects. Internationally these kinds of experiences have been studied significantly more when James lived (1842-1910) the study of these kinds of experiences was new within academe. Hence, it is later, because of increased interest in and more research in this field, not least within the disciplines of psychology, focused on consciousness and 'exceptional' experiences, that a number of different etic terms emerged internationally. Which term the researcher decides to use may depend, among other things, on tradition in the researcher's discipline, the researcher's own viewpoint and approach, the target group and the purpose of the research project.

I will not discuss all the terms that are in use in detail. What I want to do is to highlight some key trends when it comes to these terms and illustrate some issues researchers have been struggling with when considering useful terms. Below I will mainly focus on the most commonly used terms, religious and spiritual experiences, and paranormal experiences.

\section{The concept of religious experiences}

'Religious experiences' is a long-standing term in research on religion, though the definitions vary and the concept could, for instance in a Christian tradition, include having visions of Jesus or angels, or experiences of the Holy Spirit. For instance, Antoon Geels, a psychologist of religion, investigated religious visions in Sweden and asked in a newspaper advertisement: 'Have you seen or heard Jesus? Or other religious beings? Would you like to tell about your

than in the Nordic countries, hence there are more terms in the English-speaking literature than in research in the Nordic languages. For other literature overviews of some terms, see e.g. Morhed 2000: 26-32; Braud and Palmer 2002: 31, 60-1; Castro 2009: 11-15; French and Stone 2014: 7-9; White 2015; Cardeña et al. 2017; Herron 2018: 2-9. 
Aesthetic experiences (AE)

Alchemy experiences (AE)

Altered state of consciousness (ASC)

Anomalous experiences ( $A E)$

Ecstasy experiences (EE)

Encounter experiences (EE)

Epiphanic experiences (EE)

Exceptional experiences (EE, ExE)

Exceptional human experiences (EHE)

Exceptional normal experiences (ENE)

Existential experiences (EE)

Experiences deemed religious (EDR)

Extraordinary experiences (EOE)

Extrasensory perception (ESP)

Inexplicable/unexplainable experiences (IE/UE)

Intensive experiences (IE)

Kumma/uncanny experiences (KE/UE)

Luminous experiences (LU)

Mystical experiences (ME)

Mystical-type experiences (MTE)

Noetic signature (NS)

Non-ordinary experiences (NOE)

Out of the ordinary experiences (OOE)

Paranormal experiences (PE)

Peak experiences (PE)

Psychic experiences (PS)

Religious and spiritual experiences (RSE)

Religious experiences (RE)

Religious spiritual mystical experiences (RSME)

Revelatory experiences (RE)

Special experiences (SE)

Spiritual experiences (SE)

Supernatural experiences (SE)

Supernormal experiences (SE)

Transcendent experiences (TE)

Transcendent exceptional human experiences (TEHE)

Transpersonal experiences (TE)

Unusual subjective experiences (USE) experiences?' (Geels 1991: 25, my translation). Obviously, the answers received were in accordance with the questions, and the experiences were interpreted according to Christianity. In the psychology of religion researchers have often investigated, methodologically and historically, mystical experiences (mystikupplevelser) of God or a unity as part of or as an orientation within institutional religions (Sorgenfrei 2013), albeit there are a number of definitions of mystical experiences (see e.g. Geels and Wikström 2017: 217-27; Herron 2018: 2-9), and also terms within a so-called profane context, such as 'ecstasy experiences' (Laski 1961), 'peak experiences' (Maslow 1973), and 'mystical-type experiences' (Herron 2018). The terms 'religious' and 'mystical experiences' have also been used in other disciplines, for instance in relation to creativity, art and aesthetics (see e.g. Geels 1982; Stange and Taylor 2008; also see Honkasalo 2018).

However, when studying a cluster of cultural phenomena and experiences interpreted both within and outside what is usually recognized as religion it could be problematic empirically to use the concept of 'religious experiences' when collecting material among the public and people who might not identify themselves as religious in so-called secularized societies. Previous research also shows that people in general

Figure 1. The main etic terms. In disciplines such as religion, psychology, anthropology, ethnography, science of culture and art there is an indefinite intra- and interdisciplinary cross-boundary use of terms for the kinds of experiences under discussion. The main terms for a cluster of experiences are here listed, by no means exhaustively, to illustrate the variety and complexity in this field of research (the order is alphabetical; some abbreviations are recognized). 
usually associate the term 'religiosity' with institutional or organized religion, and that people may consider themselves spiritual but not religious (Sjödin 1995: 47; McGuire 2008a: 43; Willander 2008; Sorgenfrei 2013; Moberg and Ståhle 2014; Sutcliffe and Gilhus 2014; Burén 2015).

\section{The concept of 'spiritual experiences'}

In scientific studies spirituality may be included in religiosity but also distinguished from it in order to indicate a broader concern, something 'different' or 'new' that diverges from 'old' or institutional religion (see e.g. Heelas and Woodhead 2004), though it does not necessarily have to do so (see e.g. Laghé 2008; Ammerman 2013; Sorgenfrei 2013). Furthermore, the socalled 'Enköping's survey' (Ahlstrand and Gunner 2008) shows no major difference between a religious and a spiritual identity according to the researchers, since the informants perceived them as synonyms, especially those who consider themselves neither one nor the other. Willander also points out that the interviewees distinguish between being spiritual and having experienced something spiritual, and that it is more common to be involved in something that could be understood as spiritual than to perceive oneself as spiritual (Willander 2008: 247, 267-9, 273-4).

Another example illustrating the problem with the term 'spiritual' (and 'religious') is the recent study of the historian of religion David Thurfjell (2020) on people's tranquil experiences in nature, for which he instead uses the term 'existential experiences'. Thurfjell mainly interviewed citizens in the Stockholm area who were fond of nature, opening the interviews with a question such as 'What role does nature have in your life?' (p. 276, my translation), followed by questions associated with the interviewee's thoughts about this, but also questions directed at the thematic structure of his book, that is the personal, aesthetic and existential dimensions of experiences in nature. Thurfjell emphasizes that spirituality semantically has the meaning 'that which concerns the spiritual or life of the soul', but also 'the opposite of the bodily' However, this is not in agreement with the informants' experiences, which according to Thurfjell were often 'strikingly bodily'. Thurfjell further asserts that the informants in his study feel uncomfortable using words that have a religious or spiritual connotation because they associate them with dogmatic ideas, something unscientific, 'new spirituality' or a subculture that they do not want to belong to. He also stresses that language in Nordic societies has been dechristianized (pp. 216-17, 222-3, 275-6). However, this does not mean that people's existential experiences disappear or cease, only that a Christian language for these experiences is deficient or lacks relevance for his interviewees.

I have therefore chosen neither 'religious experiences' nor 'spiritual experiences' as an umbrella term encompassing these kinds of experiences. This also highlights the gap in research and knowledge in this field regarding a contemporary broader sociological perspective considering religious, cultural and societal change.

\section{The concept of 'paranormal experiences'}

In several disciplines experiences of these kinds both within and outside institutional religions are included within the chosen concept, though so-called paranormal beliefs and experiences have historically not usually been included in disciplines that investigate religion. ${ }^{6}$ However,

6 A historical exception is, for instance, the marine biologist Alister Hardy, who is known for having collected several 
this has begun to change, as advocated by a few researchers (see e.g. Taves 2009; Kripal 2010; Baker and Bader 2014; Laylock 2014; Tidelius 2020). In general, 'paranormal experiences' is a common term to denote experiences that both transcend the boundaries of generally accepted scientific explanatory models and institutional religions and their mystical traditions. Hence, the 'paranormal' has been placed in the gap between these two institutions of power and become a subject of tension (for a discussion see Baker and Draper 2010; Bromander 2008: 99-100; Tidelius 2020). However, such experiences could be regarded as 'paranormal' no matter where they occur or are interpreted, so that calling them 'paranormal' if they are not within the context of institutional religion is a matter of power, identity and legitimization.

Among others, McGuire (2008a) stresses that disciplines and researchers of religion have historically rejected experiences of these kinds outside an institutional religious context and pejoratively regarded them as 'something else, 'lower' and 'paranormal'. She concludes that there has been a notion since the beginning of Christianity about a clear distinction between institutional religion and other unorganized forms of religiosity. It is thus a question of social construction and boundaries to define and identify oneself and official orthodox Christianity as the 'correct doctrine' and 'the other' as syncretism, that is a mixture of different cultural elements, as

thousand experiences of different kinds and founding the Religious Experience Research Unit (RERU) in 1969 at the University of Wales, but eventually he decided to put other concepts he considered aside and use the term 'religious experiences' to follow the academic tradition in which he conducted his studies (Fox 2016: 16-17, 33; Yamane 2000: 171-2). something inferior and negative (pp. 97, 99, 113). Furthermore, feminist criticism, such as that of the scholar of religion Åsa Trulsson (2013), asserts that mysticism and spirituality have been defined by the patriarchal powers and associated with women's emotions, the body and nature as something 'lower' and 'worse'.

I also argue that experiences of these kinds that have occurred and been interpreted outside institutional religious contexts, belonging or beliefs should also be included and taken seriously. However, owing to the historical burden of the term 'paranormal', and with the intention of building interdisciplinary bridges, I have not considered 'paranormal experiences' to be the most useful and appropriate inclusive umbrella term for the experiences under consideration. Moreover, the prefix 'para' implies, not least historically, that these kinds of experiences are 'beside the point' of scientific research, and 'beyond the normal', when in fact recent research shows that they are relatively common, and 'normal', human experiences. ${ }^{7}$

To mention some other concepts used in a Nordic academic context, the scholar of religion Ann af Burén (2015) further categorizes 'out of the ordinary' experiences as 'secrets' to illustrate how the informants interviewed in Stockholm relate to conceptualized or imagined secular norms on the basis of science and rationality. She believes that calling these experiences 'secrets' can be a way of enchanting life and giving meaning and power to interpretations that contravene simple answers. Burén refers to the scholar of the history of ideas Karin Johannisson (2011), who emphasizes that secrets are different in different times and

7 This does not prevent some cases potentially being pathological. 
places, depending on what is considered and judged to be shameful by the prevailing ideology of the society and culture in question.

Finally, in the Finnish interdisciplinary research project 'Mind and the Other' (2013-16), the Finnish word kumma (translated as 'uncanny'; see e.g. Honkasalo 2018) has been used for varieties of experiences of the type under consideration. Although 'uncanny' may work in a so-called secular context and according to a scientific 'consensus view of reality', I perceive a pejorative connotation, since the meaning is also 'strange' or 'weird'. This is important to avoid when trying to avoid judgement or classification of these experiences as a 'mental disorder', something abnormal, pathological or 'crazy', which may have lifelong consequences and lead to stigmatization for the individuals who have had such experiences. Ethical treatment of informants may also therefore be a consideration here.

\section{Definition and understanding of the concept of 'mystical experiences'}

The title of James's classic The Varieties of Religious Experience (1902) implies that the book concerns a variety of experiences. The subtitle of the book, A Study in Human Nature, is seldom mentioned but can be interpreted as suggesting that such religious experiences are human universal experiences, though James himself mainly focused on more extreme mystical experiences and famous people. The reason for James calling the experiences religious may be due to the context and that the subject of the lectures at Gifford in Edinburgh 19012, to which he was invited and on which the book is based, was religion. However, James's definition of mystical experiences is not exclusive to traditional religious experiences (see e.g. Castro 2009: 15-16; Herron
2018). Importantly, at the turn of the nineteenth and twentieth century, James also studied contemporary spirituality and mystical experiences such as alleged contact with spirits, telepathy and mediums at seances, which were popular events at this time, particularly among the upper strata of society. James was also one of the founders of the American Society for Psychical Research (ASPR) in 1885 as a branch of the British Society (Kripal 2010: 8; Tidelius 2020: 218, 223). Thus, James was not at all limited to mystical experiences within institutional religion or orthodox Christian interpretations, which all together speaks in favour of understanding and using his concept in an encompassing and inclusive sense.

Mystical experiences have, according to James's definition, four main characteristics sufficient to mark out a group of special experiences or states, called a 'mystical group' (James 1902: 379-82). ${ }^{8}$ These kinds of experiences are often emotionally strong experiences, subjectively experienced by the individual, characterized by being (1) ineffable, that is, so emotional and different from everyday human experiences and 'the taken for granted reality' that verbal language seldom suffices to describe them. To clarify, this characteristic or trait can be divided into (a) that the experiences per se (not necessarily the stories about them) can be difficult to put into words and explain, (b) that the experiences are usually emotionally strong, and (c) take place in addition to the everyday human 'taken-for-granted reality'. This difficulty in verbalizing an emotional experience is

8 Confinement to four main characteristics is appropriate since an umbrella term like this needs to encompass several kinds of experiences and interpretations. 
not, of course, exclusive to mystical experiences; compare, for instance, describing the ordinary human experience and feeling of 'being in one's body' with that of the extraordinary experience of a so-called 'outof-body experience', or describing the feeling, including the bodily sensations, of sipping a cup of coffee or tea. Though James does not explicitly include the body in his definition, the concept of mystical experiences could include the body, not least since emotions involve the body. This is a significant consideration if a concept is to work in contemporary society.

The fact that verbal language has limitations, and that it can be difficult to verbalize emotional experiences, does not amount to diminishing these experiences or suggesting that people cannot describe what they have experienced or what has happened (see e.g. Johansson 2018), but it does mean that the emotional part of the experience per se is difficult to describe, or may simply be omitted from the story. Thus - and taking heed of the old discussion that followed James of whether mystical experience could be investigated scientifically at all (see e.g. Thurfjell 2020: 287-9) - the sociologist of religion David Yamane (2000) points out that the subjective experience per se cannot be studied, only its linguistic representation or recollection.

Relevant to this is the theologian and philosopher Rudolf Otto's (1958/1923) classical expression mysterium tremendum et fascinans, that is that these experiences can be both frightening and fascinating, referring to the characteristics of encounters with the numinous or sacred and the ineffable feelings that these often entail. In contemporary society experiences of these kinds can still be perceived as scary or frightening and may be even harder to express than hitherto. Since they do not fall within the notions and frames of secular norms, they often also give rise to fears of being regarded as naive, superstitious or dopey, or of being ridiculed, deviant or stigmatized (Morhed 2000; Burén 2015; White 2015; Koski 2016; Johansson 2018). This also illustrates the sociological perspective on the subject and the human social need to belong and be affirmed. Including both positively and negatively interpreted experiences in the research could also be regarded as more neutral and less biased.

Furthermore, these experiences often have a (2) noetic quality or properties in the sense that they may provide a kind of intuitive insight. These experiences usually also have the character of being (3) transient, that is short-lived, and often involve a feeling of (4) passivity or receptivity during the event itself. However, this passivity does not prevent a person from voluntarily trying to evoke a mystical experience or a state of consciousness beyond the ordinary, but means a kind of a receptivity outside the control of the person's will once the experience has set in. Traditional religious practices or more innovative 'new' contemporary versions of these can, for instance, be praying, fasting, deprivation of senses, meditating, practising yoga or breathing techniques, chanting, singing, listening to music, dancing, having sex, using psychedelic drugs or visiting natural, sacred or mystical places in the hope of experiencing something 'tranquil', 'exciting' or 'mysterious.'

9 External events and internal experiences do not have to be the same thing, but this is a question of bracketing because what is explored is the subjective meaning-making and interpretation of what the individual considers herself or himself to have experienced, regardless of whether it could be observed by other people as an actual event or not. 
These four characteristics of mystical experiences: (1) ineffability, (2) noetic quality, (3) transiency, and (4) passivity can substantially define and clarify what mystical experiences can be or are characterized as, although all characteristics need not necessarily be manifest, and there may be a mixture of them or a variation in degree (see also James 1902: 382). The definition can also be functionally understood as indicating meaning-making experiences and providing a form of insight, understanding, knowledge or certainty for the experiencer, regardless of whether the interpretation overall is positive or negative or a mixture of both. James also has a functional and pragmatic view on mystical experiences and emphasizes that above all they should be viewed and understood from 'the fruit they give. This can be compared to the Thomas theorem within sociology; 'If men [sic] define situations [or experiences] as real, they are real in their consequences' (Thomas and Thomas 1928: 571-2). At a higher level of theoretical abstraction, in James's (1916) pragmatism as a method of philosophical and theoretical ideas an idea or theory is found in its practical effect. Applied here, it does not matter whether scientific theories of the world are the only reality or worldview or not; the material world will still look the same and people will still make meaning of their mystical experiences.

In short, these varieties of human mystical experiences and clusters of cultural phenomena could above all be understood as a functional form of religiosity, 'lived religion' and meaning-making in contemporary society.

\section{Conclusion}

I have in this article discussed and argued for a 'new' and inclusive umbrella concept for varieties of experiences that have been called, inter alia, religious, spiritual, existential, paranormal, extraordinary or inexplicable. This umbrella concept for a cluster of often overlapping human experiences, difficult to distinguish yet in this way clearly defined, is seen as a means of capturing a kind of 'lived religion' in contemporary society, and simultaneously expanding the field of sociology of religion to include the range of ordinary people's experiences of these kinds, interpreted both within and outside institutional religions. It is crucial not to reserve or limit mystical experiences to institutional religions, given the evident degree of religious, cultural, and societal change.

I have discussed and exemplified the complexity in this field of research and shown that this discussion is not only theoretical but also of pragmatic, methodological, empirical and ethical concern. For researchers to be able to capture these phenomena empirically in so-called secular and secularized societies and a 'taken-forgranted' scientific 'consensus view of reality', James's concept of 'mystical experiences', with an upgraded and inclusive understanding considering religious, cultural and societal change, has been suggested as an inclusive umbrella concept for the kinds of experiences under consideration. I have also shown that this understanding of the concept can be anchored in theories and traditions in sociology of religion as a functional form of religiosity, 'lived religion' and meaning-making in contemporary society.

In conclusion, the concept of 'mystical experiences' has the potential to work both on etic, interdisciplinary and emic levels, without offending the experiencers or violating their interpretations and the meaning-making of their experiences, though further analysis and empirical research need to be conducted to verify this point. 
Katarina Johansson

is a Ph.D. student in sociology at the Faculty of Social Science, Åbo Akademi University. Her Ph.D. project is 'Mystical Experiences and MeaningMaking in Contemporary Society'. Her previous background is in the field of health, having an interdisciplinary and international health education and several years of professional experience as self-employed and operational manager at a multimodal health centre in Sweden, which she also established. A few years ago she started study again, receiving an MA in religious studies and theology with specialization in the history of religions and religious behavioural studies at Lund University.

\section{References}

Ahlstrand, Kajsa, and Göran Gunner (eds.). 2008. Guds närmaste stad? En studie om religionernas betydelse $i$ ett svenskt samhälle $i$ början av 20oo-talet (Stockholm: Verbum).

Ammerman, Nancy T. 2013. 'Spiritual but not religious? Beyond binary choices in the study of religion, Journal for the Scientific Study of Religion 52(2): 258-78, doi: <https://doi.org/10.1111/jssr.12024>.

Ammerman, Nancy T. 2014. Sacred Stories, Spiritual Tribes. Finding Religion in Everyday Life (Oxford University Press).

Ammerman, Nancy T. 2016. 'Lived religion as an emerging field: an assessment of its contours and frontiers', Nordic Journal of Religion and Society 29(2): 83-99, doi: <https://doi. org/10.18261/issn.1890-7008-2016-02-01>.

Aspers, Patrik. 2011. Etnografiska metoder, 2nd edn (Malmö: Liber).

Axelson, Tomas. 2014. Förtätande filmögonblick. Den rörliga bildens förmåga att beröra (Stockholm: Liber).

Baker, Joseph O., and Christopher D. Bader. 2014. 'A social anthropology of ghosts in twenty-first-century America, Social Compass 61(4): 569-93, doi: <https://doi. org/10.1177/o037768614547337>.

Baker, Joseph O., and Scott Draper. 2010. 'Diverse supernatural portfolios: certitude, exclusivity, and the curvilinear relationship between religiosity and paranormal beliefs',
Journal for the Scientific Study of Religion 49(3): 413-24, doi: <https://doi.org/10.111 1/j.1468-5906.2010.01519.x>.

Berger, Peter L., and Thomas Luckmann. 1966. The Social Construction of Reality. A Treatise in the Sociology of Knowledge (London: Penguin Books).

Bibeln. Bibelkommissionens översättning (Örebro: Libris förlag, 2000).

Braud, William, and Genie Palmer. 2002. 'Exceptional human experiences, disclosure, and a more inclusive view of physical, psychological, and spiritual well-being', The Journal of Transpersonal Psychology 34(1): 29-61.

Bromander, Jonas. 2008. 'Enköpingsstudien: en religionssociologisk analys', in Guds närmaste stad? En studie om religionernas betydelse $i$ ett svenskt samhälle $i$ början av 200o-talet, eds. Kajsa Ahlstrand and Göran Gunner (Stockholm: Verbum), 53-102.

Burén, Ann af. 2015. Living Simultaneity: On Religion among Semi-Secular Swedes (Huddinge: Södertörn University).

Calhoun, Craig, Mark Juergensmeyer, and Jonathan VanAntwerpen (eds.). 2011. Rethinking Secularism (Oxford University Press).

Cardeña, Etzel, Steven Jay Lynn, and Stanley Krippner. 2017. 'The psychology of anomalous experience: a rediscovery', Psychology of Consciousness 4(1): 4-22, doi: <https:// doi.org/10.1037/cnsooooo93 $>$.

Casanova, José. 2011. 'The secular, secularizations, secularisms', in Rethinking Secularism, eds. Craig Calhoun, Mark Juergensmeyer, and Jonathan VanAntwerpen (Oxford University Press), 54-74.

Casanova, José. 2019. Global Religious and Secular Dynamics. The Modern System of Classification (Washington, DC: Berkley Center for Religion, Peace and World Affairs Georgetown University).

Castro, Madeleine. 2009. Talking of Transcendence: A Discursive Exploration into How People Make Sense of Their Extraordinary Experiences (University of York).

Castro, Madeleine, Roger Burrows, and Robin Wooffitt. 2013. 'The paranormal is (still) normal: the sociological implications of a survey of paranormal experiences in Great Britain', Sociological Research Online 
19(3): 1-5, doi: <https://doi.org/10.5153/ sro.3355>.

Fox, Mark. 2016. Lightform: Spiritual Encounters with Unusual Light Phenomena, and edn (Worcestershire: Spirit and Sage).

French, Christopher C., and Anna Stone. 2014. Anomalistic Psychology. Exploring Paranormal Belief and Experience (New York: Palgrave Macmillan).

Frisk, Liselotte. 2014. 'Towards a new paradigm of constructing "religion": new age data and unbounded categories', in New Age Spirituality. Rethinking Religion, eds. Steven J. Sutcliffe and Ingvild Saelid Gilhus (New York: Routledge), 50-65.

Geels, Antoon. 1982. 'Mystical experience and the emergence of creativity', in Religious Ecstasy, ed. Nils G. Holm, Scripta Instituti Donneriani Aboensis 11 (Stockholm: Almqvist \& Wiksell International), 27-62, doi: <https://doi.org/10.30674/ scripta.67129>.

Geels, Antoon. 1991. Att möta Gud i kaos. Religiösa visioner i dagens Sverige (Stockholm: Norstedts förlag).

Geels, Antoon, and Owe Wikström (eds.). 2017. Den religiösa människan. En introduktion till religionspsykologin, 4 th edn (Stockholm: Natur \& Kultur).

Giddens, Anthony. 1984. The Constituion of Society. Outline of the Theory of Structuration (Berkeley: University of California Press).

Giddens, Anthony. 1999. Modernitet och självidentitet. Självet och samhället $i$ den senmoderna epoken (Göteborg: Daidalos).

Haimila, Roosa. 2020. 'Does a science-oriented worldview entail unbelief? Meaning, morality, and continuity from scientific research in self-reports of Finnish unbelievers and believers, Secular Studies 2(2): 83-116.

Hammer, Olav. 2004. På spaning efter helheten. New age - en ny folktro? (Stockholm: Wahlström \& Widstrand).

Heelas, Paul. 2014. 'On transgressing the secular: spiritualites of life, idealism, vitalism', in New Age Spirituality. Rethinking Religion, eds. Steven J. Sutcliffe and Ingvild Saelid Gilhus (New York: Routledge), 66-83.

Heelas, Paul, and Linda Woodhead. 2004. The Spiritual Revolution: Why Religion is Giving Way of Spirituality (Oxford: Blackwell Publishing).
Herron, Alice. 2018. Godless Mystics-Atheist and their Mystical Experiences: Towards a Grounded Theory (University of Surrey).

Hjarvard, Stig. 2012. 'Three forms of mediatized religion. Changing the public face of religion, in Mediatization and Religion: Nordic Perspectives, eds. Stig Hjarvard and Mia Lövheim (Göteborg: Nordicom), 21-44.

Holm, Nils G. 2011. 'Tungotal och intensiva religiösa upplevelser', in Inspiration till religionspsykologin - kultur, hälsa och mening, eds. Valerie DeMarinis, Owe Wikström, and Önver Cetrez (Stockholm: Natur \& Kultur), 227-35.

Honkasalo, Marja-Liisa. 2018. 'Neither real nor true - sharing voices in the intersubjective space and beyond', Nivel o9 (Helsinki: Theatre Academy, University of the Arts Helsinki), <https://nivel.teak.fi/carpa5/ marja-liisa-honkasalo-neither-real-nortrue-sharing-voices-in-the-intersubjectivespace-and-beyond/> (accessed 15.4.2021).

Inglehart, Ronald. 2006. 'Mapping global values', Comparative Sociology 5(2-3): 11536, doi: <https:doi.org/10.1163/156913306 $778667401>$.

James, William. 1902. The Varieties of Religious Experience. A Study in Human Nature. Being the Gifford Lectures on Natural Religion delivered at Edinburgh in 1901-1902 (New York: Longmans, Green, and Co).

James, William. 1916. Pragmatism. A New Name for Some Old Ways of Thinking. Popular Lectures on Philosophy (New York: Longmans, Green, and Co).

Johannisson, Karin. 2011. 'Hemligheters lådor, lönnfack och slöjor,' Divan: Tidskrift för Psykoanalys och Kultur 3-4: 37-51.

Johansson, Katarina. 2018. Meningsskapande $i$ samtiden. En fokusgruppundersökning om vad det innebär att tro på oförklarliga fenomen $i$ samtiden (Centre for Theology and Religious Studies, Lund University).

Josephson-Storm, Jason A. 2017. The Myth of Disenchantment: Magic, Modernity, and the Birth of Human Sciences (The University of Chicago Press).

Koski, Kaarina. 2016. 'Discussing the supernatural in contemporary Finland: discourses, genres, and forums', Folklore 65: 11-36, doi: $<$ http://dx.doi.org/10.7592/FEJF2016.65. koski $>$. 
Kripal, Jeffrey J. 2010. Authors of the Impossible. The Paranormal and the Sacred (The University of Chicago Press).

Kripal, Jeffrey J. 2011. Mutants and Mystics. Science Fiction, Superhero Comics, and the Paranormal (The University of Chicago Press).

Kurunmäki, Jussi, and Jani Marjanen. 2018. 'Begreppshistoria', in Textens mening och makt. Metodbok i samhällsvetenskaplig textoch diskursanalys, eds. Kristina Boréus and Göran Bergström, 4th edn (Lund: Studentlitteratur), 179-216.

Laghé, Birgitta. 2008. 'Andlighet och gudstjänstliv', in Guds närmaste stad? En studie om religionernas betydelse i ett svenskt samhälle i början av 20oo-talet, eds. Kajsa Ahlstrand and Göran Gunner (Stockholm: Verbum), $137-58$.

Laski, Marghanita. 1961. Ecstacy in Secular and Religious Experiences (London: Cresset Press).

Laylock, Joseph P. 2014. 'Approaching the paranormal', Nova Religio: The Journal of Alternative and Emergent Religions 18(1): 5-15, doi: $<$ https://doi.org/10.1525/nr.2014.18.1.5>.

Lövheim, Mia, and Magdalena Nordin (eds.). 2015. Sociologiska perspektiv på religion $i$ Sverige (Malmö: Gleerups Utbildning).

Luckmann, Thomas. 1967. The Invisible Religion. The Problem of Religion in Modern Society (New York: Macmillan Company).

Luckmann, Thomas. 1990. 'Shrinking transcendence, expanding religion', Sociological Analysis 50(2): 127-38, doi: <https://doi. org/10.2307/3710810>.

Luhrmann, Tanya M. 2012. When God Talks Back: Understanding the American Evangelical Relationship with God (New York: Knopf).

Maslow, Abraham. 1973. Religion, Values, and Peak-Experiences (New York: The Viking Press).

McGuire, Meredith B. 2008a. Religion. The Social Context (Long Grove, IL: Waveland Press).

McGuire, Meredith B. 2008b. Lived Religion: Faith and Practice in Everyday Life (Oxford University Press).

Moberg, Jessica, and Göran Ståhle (eds). 2014. Helig hälsa. Helandemetoder $i$ det mångreligiösa Sverige (Stockholm: Dialogos).
Morhed, Sven-Eric. 2000. Att förklara det oförklarliga. En livsåskådningsstudie av människors tolkningar av paranormala fenomen $i$ en vetenskaplig tidsålder (Uppsala: Acta Universitatis Upsaliensis).

Otto, Rudolf. 1958/1923. The Idea of the Holy. An Inquiry into the Non-Rational Factor in the Idea of the Divine and its Relation to the Rational (Oxford University Press), first published in 1923.

Partridge, Christopher 2004. The Re-Enchantment of the West: Alternative Spiritualities, Sacralization, Popular Culture, and Occulture, vol. 1 (London: T\&T Clark International).

Riis, Ole, and Linda Woodhead. 2010. A Sociology of Religious Emotion (Oxford University Press).

Rosén, Ina. 2009. I'm a Believer - But I'll Be Damned if I'm Religious. Belief and Religion in the Greater Copenhagen Area: A Focus Group Study (Centre for Theology and Religious Studies, Lund University).

Rothstein, Mikael. 2014. 'Dolphins and other humans: new age identities in comparative perspective', in New Age Spirituality. Rethinking Religion, eds. Steven J. Sutcliffe and Ingvild Saelid Gilhus (New York: Routledge), 117-31.

Schütz, Alfred. 1982/1962. Collected Papers I. The Problem of Social Reality, ed. Maurice Natanson (The Hague: Martinus Nijhoff), first published in 1962.

Schütz, Alfred, and Thomas Luckmann. 1973. The Structures of the Life-World (Evanston, IL: Northwestern University Press).

Selberg, Torunn. 2011. Folkelig religiositet. Et kulturvitenskapligt perspektiv (Oslo: Spartacus).

Sjödin, Ulf. 1995. Flygande tefat, spöken och sanndrömmar. Ungdomars syn på paranormala företeelser (Uppsala: Religionsvetenskapliga förlaget).

Sorgenfrei, Simon. 2013. 'Mystik, esoterism och andlighet. En begreppshistorisk översikt', in Mystik och andlighet. Kritiska perspektiv, ed. Simon Sorgenfrei (Stockholm: Dialogos), 9-37.

Stange, Ken, and Shelley Taylor. 2008. 'Relationship of personal cognitive schemas to the labeling of a profound emotional experience as religious-mystical or aesthetic', 
Empirical Studies of the Arts 26(1): 37-49, doi: <https://doi.org/10.2190/EM.26.1.d >.

Sutcliffe, Steven J., and Ingvild Saelid Gilhus (eds.). 2014. New Age Spirituality. Rethinking Religion (New York: Routledge).

Taves, Ann. 2009. Religious Experience Reconsidered: A Building-Block Approach to the Study of Religion and Other Special Things (Princeton University Press).

Taylor, Charles. 1989. Sources of the Self. The Making of the Modern Identity (Cambridge University Press).

Taylor, Charles. 2011. 'Western secularity', in Rethinking Secularism, eds. Craig Calhoun, Mark Juergensmeyer, and Jonathan VanAntwerpen (Oxford University Press), 31-54.

Tegmark, Max. 2014. Vårt matematiska universum. Mitt sökande efter den yttersta verkligheten (Stockholm: Volante).

Thomas, William Isaac, and Dorothy Swaine Thomas. 1928. The Child in America: Behavior Problems and Programs (New York: Knopf).

Thurfjell, David. 2016. 'Religion finns inte! Svar från kritisk religionsteori, in Varför finns religion?, ed. David Thurfjell (Stockholm: Molin \& Sorgenfrei), 250-68.

Thurfjell, David. 2020. Granskogsfolk. Hur naturen blev svenskarnas religion (Stockholm: Norstedts).

Tidelius, Cristoffer. 2020. 'The paranormal. Conceptualization in previous research', in Approaching Esotericism and Mysticism: Cultural Influences, eds. Maarit LeskeläKärki and Tiina Mahlamäki, Scripta Instituti Donneriani Aboensis 29 (Turku: Donner Institute), 216-38, doi: <https://doi. org/10.30674/scripta.84823>.

Trulsson, Åsa. 2013. 'Postsekulär mystik? Makt och genus i samtida andlighet', in Mystik och andlighet. Kritiska perspektiv, ed. Simon Sorgenfrei (Stockholm: Dialogos), 174-98.

Weber, Max. 1964/1922. The Sociology of Religion (Boston: Beacon Press), first published in 1922.

White, Rhea A. 2015. 'Dissociation, narrative, and exceptional human experiences', in Broken Images, Broken Selves. Dissociative Narratives in Clinical Practice, eds. Stanley Krippner and Susan Marie Powers, 2nd edn (New York: Routledge), 88-121.
Willander, Erika. 2008. 'Avslappnad och berörd. Synen på hälsa och andlighet bland hälsofrämjande företag i Enköping, in Guds närmaste stad? En studie om religionernas betydelse $i$ ett svenskt samhälle $i$ början av 200o-talet, eds. Kajsa Ahlstrand and Göran Gunner (Stockholm: Verbum), 241-76.

Willander, Erika. 2014. What Counts as Religion in Sociology? The Problem of Religiosity in Sociological Methodology (Uppsala universitet: Elanders Sverige).

Willander, Erika. 2015. 'Religiositet och sekularisering, in Sociologiska perspektiv på religion $i$ Sverige, eds. Mia Lövheim and Magdalena Nordin (Malmö: Gleerups), 53-68.

Willander, Erika. 2019. Sveriges religiösa landskap - samhörighet, tillhörighet och mångfald under 200o-talet, SST:s skriftserie 8 (Bromma: Myndigheten för stöd till trossamfund).

Wittgenstein, Ludwig. 2021/1953. Filosofiska undersökningar (Stockholm: Thales), first published in 1953.

Woodhead, Linda. 2011. 'Five concepts of religion', International Review of Sociology 21(1): 121-43, doi: <https://doi.org/10.108 o/03906701.2011.544192>.

Yamane, David. 2000. 'Narrative and religious experience', Sociology of Religion 61(2): 17189, doi: <https://doi.org/10.2307/3712284>. 